\title{
Nutrient content and shelf life analysis of freshwater snail (Pila ampullacea) instant baby porridge
}

\author{
${ }^{1}$ Ihsani, K., ${ }^{1}$ Afifah, D.N., ${ }^{2}$ Anantyo, D.T., ${ }^{2}$ Mulyono, ${ }^{2}$ Nugroho, T.W., ${ }^{2}$ Wahyudi, F. and \\ ${ }^{1, *}$ Nuryanto \\ ${ }^{I}$ Department of Nutrition Science, Faculty of Medicine, Universitas Diponegoro Jl. Prof H. Soedarto, SH, \\ Tembalang, Semarang 50275, Indonesia \\ ${ }^{2}$ Medicine Department, Faculty of Medicine, Diponegoro University, Jl. Prof H. Soedarto, SH, Tembalang, \\ Semarang 50275, Indonesia
}

\author{
Article history: \\ Received: 31 January 2020 \\ Received in revised form: 13 \\ April 2020 \\ Accepted: 26 September 2020 \\ Available Online: 1 \\ November 2020
}

\section{Keywords:}

Freshwater snail flour,

Baby porridge,

Nutrient content,

Acceptability,

Shelf life

DOI:

https://doi.org/10.26656/fr.2017.4(S3).S20

\begin{abstract}
The quality of instant baby porridge leads to nutrient content, consumer's acceptability and shelf life. The use of freshwater snail flour (Pila ampullacea) as a substitution in the product increases the product nutrition value. The study analyzed nutrients content, acceptability, and shelf life of instant baby porridge. An experimental study with a completely randomized single factor design by using the three ratios of freshwater snail flour KS $0(0 \%)$, KS I (10\%), and KS II (15\%). The acceptability test (hedonic test) was held on 25 semi-trained panelists and Arrhenius for shelf life analysis. Data were analyzed using One-way ANOVA, Krusskal wallis test, and Mann-Whitney. The substitution of freshwater snail flour could affect the nutrient content of carbohydrate, protein, fat, fiber, water, ash, iron, zinc, and calcium $(\mathrm{p}<0.05)$. The substitution could affect the consumer's acceptance properties include color, flavor, texture, and taste $(\mathrm{p}<0.05)$. The shelf-life testing for 15 days obtained results, $\mathrm{KS} 0$ formula in temperature $35^{\circ} \mathrm{C}, 45^{\circ} \mathrm{C}$ and $50^{\circ} \mathrm{C}$ is $7.13 ; 2.13$ and 2.16 months respectively. KS I Formula in temperature $35^{\circ} \mathrm{C}, 45^{\circ} \mathrm{C}$ and $50^{\circ} \mathrm{C}$ is $39,40,41$ days. KS II Formula in temperature $35^{\circ} \mathrm{C}, 45^{\circ} \mathrm{C}$ and $50^{\circ} \mathrm{C}$ is 6 years 7 months, 6 years 8 months, and 6 years 9 months. Based on nutrient content analysis, the substitution of freshwater snail flour could have enhanced protein, zinc, iron, calcium, and fat. KS I, the best formula obtained has $20 \mathrm{~g}$ contribution in one serving, fulfilled the energy adequacy of $14.41 \%$, carbohydrates, $15.36 \%$, protein $17.7 \%$, fat $10.27 \%$, fiber $1.7 \%$, water $0.16 \%$, iron $11.25 \%$, zinc $10 \%$, calcium $35.10 \%$ and the shelf life in temperature of $35^{\circ} \mathrm{C}$ is 39 days, $45^{\circ} \mathrm{C}$ has a shelf life of 40 days and $50^{\circ} \mathrm{C}$ has a shelf life of 41 days.
\end{abstract}

\section{Introduction}

Stunting problems can still be handled during the first 1000 days of life or the golden period (ages 0-24 months). This period is a very important period as well as a critical period of the growth process and cognitive development (Victora et al., 2008). Consumption of food in sufficient quantities and nutritional content is important for children's growth and development to grow healthy, strong, and smart. After the age of 6 months, breastfed infants are increasingly difficult to meet their nutrient needs from human milk alone. Because babies need more energy increased by $24-30 \%$ compared to the needs at the age of 3-5 months (WHO, 2000; Trahms and McKean, 2008). Then, they can be given complementary feeding after babies aged 6 months.

The public knows that there are two types of complementary feeding, i.e., traditional complementary feeding and factory food. Traditional complementary feeding processing often does not meet the food sanitation hygiene principles to disable the contamination of microorganisms that cause diarrhea in infants (Kusumawardani, 2010). Meanwhile, complementary feeding factory produced baby food that is relatively more hygienic and practical to serve. The nutritional content in the complementary feeding can be formulated on the nutritional adequacy rate of babies (Hadiningsih, 2004). Complementary feeding known to the public is instant baby porridge. To increase the 
nutritional content of instant baby porridge complementary feeding, the ingredient in the making is substituted with one of the potential local foodstuffs in Grobogan, i.e., freshwater snail (Pila ampullacea).

Pila ampullacea is a native mollusk commonly found throughout the Southeast Asian region. Pila ampullacea is known as a parasite in the fields, although its meat is widely consumed as a food. Pila is a genus of large water snails, anna aquatic gastropod mollusk of the family Ampullariidae (Obande et al., 2013). The reveal invertebrates (snails) may serve as paratenic hosts for the parasite nematode Gnathostoma spinigerum, causing Gnathostomiasis. The infection is caused when the raw or undercooked snail harboring the larvae are eaten or improperly cooked (WHO, 1995; Komalamisra et al., 2009).

$100 \mathrm{~g}$ of freshwater snail meat contains several high nutrients, such as energy $209.49 \mathrm{kcal}$, protein $18.8 \mathrm{~g}$, calcium $812 \mathrm{mg}$, zinc $12 \mathrm{mg}$, and iron $102 \mathrm{mg}$. This material can be processed into complementary foods high in nutrients to improve the nutritional status of children and prevent nutritional deficiencies (Nurhasan et al., 2018). Calcium content in freshwater snail is higher than calcium in $100 \mathrm{~g}$ of beef $7 \mathrm{mg}$, liver $6 \mathrm{mg}$, eggs $54 \mathrm{mg}$ and milk $120 \mathrm{mg}$ (Obande et al., 2013; Oktasari, 2014).

Instant complementary food is said good if eligible for consumption, i.e, with food quality testing. It can be by estimating shelf life. Shelf life is one of the limits secured to the quality of products in good condition when consumed and does not endanger consumers. If a product has a short shelf life, the microbiological changes will be faster. It will reduce the value of product quality and consumer safety. Products that have a shelf life of medium to long changes will occur, namely chemical and sensory changes (Herawati, 2008; Asiah et al., 2018). Hedonic assessment is the economical and ideal method to find out the influence of variations in ingredients, production, packaging, or shelf life. (Sharif et al., 2017). In addition to attention to the nutritional content and shelf life of the product, the product must also pay attention to consumer acceptance and happiness for color, aroma, texture, and taste through acceptability test. Acceptability test has a high relevance to qualities of the product because it is directly related to consumer taste (Ayustaningwarno, 2014). In the early stages of product development, sensory testing can pinpoint the imperative sensory characteristics driving acceptability (Actia, 2001).

Instant baby porridge complementary feeding is good alternative because it has a higher advantage than mostly baby porridge. The shelf life product is a longer, practical, economic, and hygiene. Instant baby porridge complementary feeding for infants aged 6-12 months was safe for consumption within 24 months after the date of production (Republic Indonesia Health Minister, 2007). The purpose of this study is to analyze the nutrient content, acceptance product, and shelf life of the formulation instant baby porridge complementary feeding with the substitution of freshwater snail (Pila ampullacea) for development of an alternative food into a healthy complementary feeding local food, solid energy and solid nutrient, which is intended to support the fulfillment of the intake of children aged 6-12 months.

\section{Materials and methods}

\subsection{Material}

The ingredients of this instant baby porridge complementary feeding are rice flour, full cream milk, refined sugar, vegetable oil and freshwater snail meat obtained from Grobogan Regency, Central Java, Indonesia.

\subsection{Method}

This study was an experimental research with a Completely Randomized Design (CRD), one factor, which is the formulation of instant baby porridge with the substitution of freshwater snail flour. This study consists of three stages, i.e., the process of processing freshwater snail into powder, rice flour pregelatinization processing and making formulation of instant baby porridge complementary feeding.

\subsubsection{Sample preparation}

\subsubsection{Processing of freshwater snail flour}

In the first step, freshwater snail meat was cleaned and boiled for 30 mins. Then, the snail meat was cut into thin strips and dried under the electric oven for $1 \mathrm{hr}$ at 75 $-80^{\circ} \mathrm{C}$. The dried snail meat strips were ground until smooth and sieved using a 60 -mesh sieve.

\subsubsection{Pregelatinization of rice flour}

Rice flour was dissolved in water in a ratio 1: 4 and cooked until the suspension thickens, forming a paste. The paste was put into a twin drum drying at a rotational speed of $1.5 \mathrm{rpm}$ and dried at $110^{\circ} \mathrm{C}$ into rice flour film sheets. The rice flour film sheets was ground and sieved using the 60-mesh sieve.

\subsubsection{Formulation of instant baby porridge}

All dry ingredients were mixed following the formulations in Table 1. Oil was added and stirred well. 
Table 1. Formulation sample of instant baby porridge complementary feeding

\begin{tabular}{lccc}
\hline \multirow{2}{*}{\multicolumn{1}{c}{ Material }} & Control & \multicolumn{2}{c}{ Formulation } \\
\cline { 3 - 4 } & Group & \multicolumn{2}{c}{} \\
\cline { 3 - 4 } & KS 0 (\%) & KS I (\%) & KS II (\%) \\
\hline Freshwater Snail flour & - & 10 & 15 \\
Rice Flour & 35 & 35 & 35 \\
Full cream milk & 50 & 40 & 35 \\
Refined sugar & 5 & 5 & 5 \\
Vegetable oil & 10 & 10 & 10 \\
\hline Total & 100 & 100 & 100 \\
\hline
\end{tabular}

\subsubsection{Nutrient analysis}

Freshwater snail instant baby porridge complementary feeding was analyzed for the energy and nutrient content (carbohydrate, fat, protein, fiber, zinc, iron, and calcium). Each test was carried out with three repetitions. The energy content was analyzed using Bomb calorimeter, carbohydrates using carbohydrate-bydifference, protein using Kjeldahl, fat using Soxhlet, fiber and ash using Gravimetric, water content using oven, iron, zinc and calcium using AAS (Atomic Absorption Spectroscopy).

\subsubsection{Acceptability test}

The hedonic approach, on the other hand, studies the acceptability or preference by an identified group of consumers, for a food product, by assessing the happiness caused by that product when tasted or consumed. Samples of all three instant formulations of instant baby porridge were prepared by mixing warm water at a ratio of 1 (sample): 3 (water). A total of 25 semi-trained panelists comprising of Nutrition Science students of the Diponegoro University, Indonesia were asked to score the samples using 4 likeness scale (1 very dislike to 4 - like most) based on the color, aroma, texture and taste (Lim, 2011).

\subsubsection{Shelf life analysis}

Shelf life was analyzed using the Arrhenius model of Accelerated Shelf Life Testing (ASLT) method based on total plate count (TPC) and water activity $\left(\mathrm{a}_{\mathrm{w}}\right)$ value using 3 variations of storage temperature $35^{\circ} \mathrm{C}, 45^{\circ} \mathrm{C}$, and $50^{\circ} \mathrm{C}$ tested once every three days for 15 days. The selection of storage temperature was based on guidelines for determining the temperature of shelf life on dry food (Labuza and Schmidl, 1985). Complementary food products are packaged in aluminum foil sachets by milk powder packaging provisions (Cesa et al., 2015). The test was carried out twice. There were 120 samples to be analyzed. Data obtained from $\mathrm{a}_{\mathrm{w}}$ were plotted against time and three product storage temperatures to produce a linear regression equation: $\mathrm{y}=\mathrm{kx}+\mathrm{a}$ (Asiah et al., 2018). $y$ is the characteristic value of the product, $x$ is the storage time (days), $\mathrm{k}$ is the rate of the characteristic change (slope $=$ rate of decline in quality), and a is the initial product characteristic value from the linear regression equation. The value of quality regression constant $(\mathrm{k})$ is obtained from the linear regression equation, then $\ln \mathrm{k}$ is plotted with $1 / \mathrm{T}$ to result in the intercept and slope value of the linear regression equation $\ln \mathrm{k}=\ln \mathrm{k} 0-(\mathrm{Ea} / \mathrm{R})(1 / \mathrm{T})$. After obtaining the activation energy characteristics and the value of $\mathrm{k} 0$, the Arrhenius equation was calculated by the formula $\mathrm{k}=\mathrm{k}_{\mathrm{o}}$ $\mathrm{e}^{\mathrm{E} / \mathrm{RT}}$ or $\ln \mathrm{k}=\mathrm{ko}-\mathrm{E} / \mathrm{RT}$. $\mathrm{k}$ is the reaction rate constant/ constant decrease in temperature, $\mathrm{k}_{\mathrm{o}}$ is the so-called preexponential factor (independent of temperature), $\mathrm{E}$ is the apparent activation energy ( $\mathrm{cal} / \mathrm{mol}), \mathrm{R}$ is the molar gas constant $1.986(\mathrm{cal} / \mathrm{mol} \mathrm{K})$, and $\mathrm{T}$ is the absolute temperature in Kelvin $\left({ }^{\circ} \mathrm{C}+273\right)$ (Calligaris et al., 2019).

The $\mathrm{k}$ value obtained will be entered into the equation of the reaction sequence: $\mathrm{t}=(\mathrm{A} 0-\mathrm{A}) / \mathrm{k}$ or $\mathrm{t}=$ $(\ln \mathrm{A} 0-\ln \mathrm{A}) \mathrm{k}($ Asiah et al., 2018). $\mathrm{t}$ is the predicted shelf life (days), A0 is the Initial value of shelf life, A is the final value of shelf life, and $\mathrm{k}$ is the reaction rate constant decrease in quality at a normal temperature shelf life of instant baby porridge complementary feeding with the specified amount of snails will be obtained.

\subsection{Statistical analysis}

The statistical was analyzed by using a One-way ANOVA test for nutrient content analysis and Krusskal wallis test with Mann-Whitney follow-up test for acceptability (hedonic test).

\section{Results}

\subsection{Energy and Nutrient Content}

Table 2 shows the results of the energy analysis and the nutrient content product. The statistical was analyzed of nutrient content of instant baby porridge substituted with freshwater snail (Pila ampullacea) flour with a treatment level of $10 \%, 15 \%$ and not substituted with freshwater snail (Pila ampullacea) flour. There was an influence of freshwater snail flour substitution for carbohydrate, protein, fat, water content, ash, crude fiber, iron, zinc and calcium $(\mathrm{P}<0.05)$.

\subsection{Acceptability test}

Instant baby porridge with freshwater snail flour substitution produces white-fine powder like thick-ash milk powder and ready to eat after poured warm water with a ratio of $1: 3$. The results of the acceptability analysis of the color, aroma, texture and taste of instant baby porridge can be seen in the appendix and briefly 
Table 2. Nutrient content composition of freshwater snail instant baby porridge formulation

\begin{tabular}{lccccc}
\hline \multirow{2}{*}{ Nutrient } & \multicolumn{3}{c}{ Formulation } & \multirow{2}{*}{ Standard } & \multirow{2}{*}{ P-value } \\
\cline { 2 - 4 } & KS 0 & KS I & KS II & & \\
\hline Energy (kcal) & 504.33 & 522.62 & 509.98 & $440-440$ & \\
Carbohydrate (g) & $67.72 \pm 0.01^{\mathrm{a}}$ & $63.01 \pm 0.04^{\mathrm{b}}$ & $59.67 \pm 0.06^{\mathrm{c}}$ & - & 0 \\
Fat (g) & $19.99 \pm 0.01^{\mathrm{a}}$ & $18.31 \pm 0.02^{\mathrm{b}}$ & $18.99 \pm 0.79^{\mathrm{c}}$ & $10-15$ & 0 \\
Protein (g) & $10.41 \pm 0.00^{\mathrm{a}}$ & $16.18 \pm 0.02^{\mathrm{b}}$ & $18.97 \pm 0.03^{\mathrm{c}}$ & $15-22$ & 0 \\
Fiber (g) & $2.44 \pm 0.01^{\mathrm{a}}$ & $3.55 \pm 0.04^{\mathrm{b}}$ & $3.99 \pm 0.06^{\mathrm{c}}$ & Maximum 5 & 0 \\
Water (g) & $5.51 \pm 0.01^{\mathrm{a}}$ & $6.24 \pm 0.01^{\mathrm{b}}$ & $6.22 \pm 0.01^{\mathrm{b}}$ & Maximum 4 & 0 \\
Ash (g) & $1.88 \pm 0.01^{\mathrm{a}}$ & $2.49 \pm 0.03^{\mathrm{b}}$ & $2.68 \pm 0.03^{\mathrm{c}}$ & 3.5 & 0 \\
Iron (mg) & $1.88 \pm 0.02^{\mathrm{a}}$ & $4.72 \pm 0.07^{\mathrm{b}}$ & $6.61 \pm 0.06^{\mathrm{c}}$ & $5-8$ & 0 \\
Zinc (mg) & $1.03 \pm 0.01^{\mathrm{a}}$ & $1.27 \pm 0.01^{\mathrm{b}}$ & $1.61 \pm 0.00^{\mathrm{c}}$ & $2.5-4.0$ & 0 \\
Calcium (mg) & $208.45 \pm 0.64^{\mathrm{a}}$ & $438.80 \pm 0.00^{\mathrm{b}}$ & $621.55 \pm 0.07^{\mathrm{c}}$ & $200-400$ & 0 \\
\hline
\end{tabular}

Means with different superscript letter are significantly different by Tukey test $\alpha=0.05$.

Table 3. Mean results of the acceptance test analysis of instant baby porridge

\begin{tabular}{ccccccccc}
\hline \multirow{2}{*}{ Formula } & \multicolumn{2}{c}{ Color } & \multicolumn{2}{c}{ Flavor } & \multicolumn{2}{c}{ Taste } & \multicolumn{2}{c}{ Texture } \\
\cline { 2 - 9 } & Mean & Info & Mean & Info & Mean & Info & Mean & Info \\
\hline KS 0 & $3.4 \pm 0.60$ & like & $3.5 \pm 0.61$ & like & $2.8 \pm 0.91$ & Dislike & $3.4 \pm 0.59$ & like \\
KS I & $3.0 \pm 0.64$ & like & $2.6 \pm 0.68$ & dislike & $2.6 \pm 0.59$ & Dislike & $3.05 \pm 0.60$ & like \\
KS II & $2.4 \pm 0.59$ & dislike & $2.2 \pm 0.62$ & Dislike & $2.1 \pm 0.64$ & Dislike & $2.75 \pm 0.55$ & Dislike \\
P value & $\mathrm{p}=0.000$ & \multicolumn{2}{c}{$\mathrm{p}=0.000$} & $\mathrm{p}=0.005$ & $\mathrm{p}=0.015$ \\
\hline
\end{tabular}

Different test was evaluated using the Kruskal Wallis test

Table 4. Results of analysis of average activity water for testing shelf life

\begin{tabular}{lcccccccccc}
\hline \multirow{2}{*}{ Calculation } & \multirow{2}{*}{ Time } & \multicolumn{3}{c}{$\mathrm{a}_{\mathrm{w}}(\mathrm{KS} 0)$} & \multicolumn{3}{c}{$\mathrm{a}_{\mathrm{w}}(\mathrm{KS} \mathrm{I})$} & \multicolumn{3}{c}{$\mathrm{a}_{\mathrm{w}}(\mathrm{KS} \mathrm{II})$} \\
\cline { 3 - 11 } & & $35^{\circ} \mathrm{C}$ & $45^{\circ} \mathrm{C}$ & $50^{\circ} \mathrm{C}$ & $35^{\circ} \mathrm{C}$ & $45^{\circ} \mathrm{C}$ & $50^{\circ} \mathrm{C}$ & $35^{\circ} \mathrm{C}$ & $45^{\circ} \mathrm{C}$ & $50^{\circ} \mathrm{C}$ \\
\hline \multirow{4}{*}{ Ordo 0} & 0 day & 0.319 & 0.319 & 0.319 & 0.3145 & 0.3145 & 0.3145 & 0.3045 & 0.3045 & 0.3045 \\
& 5 days & 0.414 & 0.347 & 0.324 & 0.366 & 0.316 & 0.2635 & 0.373 & 0.2965 & 0.2725 \\
& 10 days & 0.3605 & 0.276 & 0.249 & 0.343 & 0.267 & 0.233 & 0.3425 & 0.251 & 0.233 \\
& 15 days & 0.364 & 0.281 & 0.199 & 0.353 & 0.251 & 0.172 & 0.3435 & 0.236 & 0.172 \\
\hline \multirow{4}{*}{ Ordo 1 } & 0 day & -1.14 & -1.14 & -1.14 & -1.16 & -1.16 & -1.16 & -1.3 & -1.3 & -1.3 \\
& 5 days & -0.88 & -1.06 & -1.13 & -1.01 & -1.15 & -1.33 & -0.99 & -1.22 & -1.3 \\
& 10 days & -1.18 & -1.29 & -1.39 & -1.07 & -1.32 & -1.55 & -1.07 & -1.38 & -1.46 \\
& 15 days & -1.01 & -1.27 & -1.61 & -1.04 & -1.38 & -1.71 & -1.07 & -1.44 & -1.76 \\
\hline
\end{tabular}

presented in Table 3. Based on the analysis of the test results of the level of complementary feeding acceptance of baby porridge with freshwater snail flour substitution, there are significant differences in the aspects of color $(\mathrm{p}$ $=0.000)$, aroma $(\mathrm{p}=0.000)$, texture $(\mathrm{p}=0.005)$, taste $(\mathrm{p}$ $=0.015$ ).

\subsection{Shelf life}

If the reaction of stored food damage is not known for its ordo reaction model, then a plot of values can be done in either ordo 0 or ordo 1 . In ordo 0 , the plot is made between the average of the observed score and the storage time. Meanwhile, the ordo 1 score average score is first changed in the form $(\ln )$ and then plotted with the storage time.

Table 4 shows the analysis of the average value of $\mathrm{a}_{\mathrm{w}}$ at three storage temperatures $\left(35^{\circ} \mathrm{C}, 45^{\circ} \mathrm{C}, 50^{\circ} \mathrm{C}\right)$. The value of the $\mathrm{a}_{\mathrm{w}}$ is plotted so that the regression equation is obtained, and regression coefficient $\left(\mathrm{R}^{2}\right)$ is determined. The choice of the kinetics of the reaction order is done by comparing the correlation coefficient $\left(\mathrm{R}^{2}\right)$ for each linear regression equation. A reaction ordo with a greater $R^{2}$ value is the reaction used, so in the estimation of shelf life based on the $\mathrm{a}_{\mathrm{w}}$, follows the one ordo reaction. In Table 5, a graph of the rate of change $\mathrm{a}_{\mathrm{w}}$ in instant baby porridge during the storage period. After obtaining a regression equation for each storage temperature, an Arheniuss plot is done with the $\mathrm{x}$ axis representing $1 / \mathrm{T}$ and the $\mathrm{y}$ axis representing $\ln \mathrm{k}$ (Table $6)$.

The $\mathrm{k}$ value shows the gradient of the linear regression obtained from the three storage temperatures, while $\mathrm{T}$ is the storage temperature used. The values of $\mathrm{k}$ and $\mathrm{I} / \mathrm{T}$ are plotted in a graph, then a graph obtained to each formula to the order and from the equation on the graph can be obtained the value of activation energy and ln ko (Table 7). ko is a constant decrease in quality stored at normal temperatures, $\mathrm{k}$ is an absolute decrease in quality of one of the conditions used while $\mathrm{E} / \mathrm{k}$ is a 
Table 5. Linear regression equation of activity water parameters

\begin{tabular}{cccccc}
\hline \multirow{2}{*}{ Formulation Temperature } & \multicolumn{2}{c}{ Regression Equation } & \multicolumn{2}{c}{$\mathrm{R}^{2}$} \\
\cline { 2 - 6 } & & Ordo 0 & Ordo 1 & Ordo 0 & Ordo 1 \\
\hline \multirow{3}{*}{ KS 0 } & $35^{\circ} \mathrm{C}$ & $\mathrm{y}=0.0028 \mathrm{x}+0.344$ & $\mathrm{y}=0.0095 \mathrm{x}-1.0782$ & 0.0053 & 0.0081 \\
& $45^{\circ} \mathrm{C}$ & $\mathrm{y}=0.0435 \mathrm{x}+0.3815$ & $\mathrm{y}=0.0619 \mathrm{x}+1.0339$ & 0.8786 & 0.5372 \\
& $50^{\circ} \mathrm{C}$ & $\mathrm{y}=0.0188 \mathrm{x}+0.3815$ & $\mathrm{y}=0.1679 \mathrm{x}-0.8988$ & 0.5195 & 0.8789 \\
\hline \multirow{3}{*}{ KS I } & $35^{\circ} \mathrm{C}$ & $\mathrm{y}=0.0092 \mathrm{x}+0.321$ & $\mathrm{y}=0.0282 \mathrm{x}-1.1387$ & 0.2979 & 0.3158 \\
& $45^{\circ} \mathrm{C}$ & $\mathrm{y}=0.024 \mathrm{x}+0.347$ & $\mathrm{y}=0.0845 \mathrm{x}-1.0416$ & 0.8709 & 0.8766 \\
& $50^{\circ} \mathrm{C}$ & $\mathrm{y}=0.0451 \mathrm{x}+0.3558$ & $\mathrm{y}=0.187 \mathrm{x}-0.969$ & 0.9896 & 0.9976 \\
\hline \multirow{3}{*}{$\mathrm{KS} \mathrm{II}$} & $35^{\circ} \mathrm{C}$ & $\mathrm{y}=0.0183 \mathrm{x}+0.2873$ & $\mathrm{y}=0.0609 \mathrm{x}-1.2589$ & 0.305 & 0.3398 \\
& $45^{\circ} \mathrm{C}$ & $\mathrm{y}=0.0155 \mathrm{x}+0.3028$ & $\mathrm{y}=0.0598 \mathrm{x}-1.186$ & 0.5771 & 0.6051 \\
& $50^{\circ} \mathrm{C}$ & $\mathrm{y}=0.0341+0.3228$ & $\mathrm{y}=0.1537 \mathrm{x}-1.07$ & 0.86 & 0.8368 \\
\hline
\end{tabular}

Table 6. Value of k, 1/T and ln k (parameters of Arrhenius-Equation of water activity values during storage)

\begin{tabular}{cccccccc}
\hline \multirow{2}{*}{ Formulation } & Temperature & \multicolumn{3}{c}{$\mathrm{a}_{\mathrm{w}}$ ordo 0} \\
\cline { 3 - 8 } & $(\mathrm{T}){ }^{\circ} \mathrm{C}$ & Slope $(\mathrm{k})$ & $1 / \mathrm{T}$ & $\ln \mathrm{k}$ & Slope $(\mathrm{k})$ & $1 / \mathrm{T}$ & $\ln \mathrm{k}$ \\
\hline \multirow{3}{*}{$\mathrm{KS} 0$} & $35^{\circ} \mathrm{C}$ & 0.0028 & 0.0286 & 5.8781 & 0.0095 & 0.0286 & 4.6565 \\
& $45^{\circ} \mathrm{C}$ & 0.0435 & 0.0222 & 3.135 & 0.0619 & 0.0222 & 2.7822 \\
& $50^{\circ} \mathrm{C}$ & 0.0188 & 0.02 & 3.9739 & 0.1679 & 0.02 & 1.7844 \\
\hline \multirow{3}{*}{$\mathrm{KS} \mathrm{I}$} & $35^{\circ} \mathrm{C}$ & 0.0092 & 0.0286 & 4.6886 & 0.0092 & 0.0286 & 4.6886 \\
& $45^{\circ} \mathrm{C}$ & 0.024 & 0.0222 & 3.7297 & 0.024 & 0.022 & 3.7297 \\
& $50^{\circ} \mathrm{C}$ & 0.0451 & 0.02 & 3.0989 & 0.0451 & 0.02 & 3.0989 \\
\hline \multirow{3}{*}{$\mathrm{KS} \mathrm{II}$} & $35^{\circ} \mathrm{C}$ & 0.0183 & 0.0286 & 4.0009 & 0.0183 & 0.0286 & 4.0009 \\
& $45^{\circ} \mathrm{C}$ & 0.0155 & 0.0222 & 4.1669 & 0.0155 & 0.022 & 4.1669 \\
& $50^{\circ} \mathrm{C}$ & 0.0031 & 0.02 & 3.3785 & 0.0341 & 0.02 & 3.3785 \\
\hline
\end{tabular}

Table 7. Value of equation, energy activation and Ln ko

\begin{tabular}{ccccc}
\hline Formulation & & Equation ln $\mathrm{k}$ & $\begin{array}{c}\text { Energy activation (E) } \\
\text { cal/mol }\end{array}$ & Ln ko \\
\hline \multirow{3}{*}{ Ordo 0 } & KS 0 & $\mathrm{y}=0.9521 \mathrm{x}-6.2332$ & 0.79956 & -6.2332 \\
& KS I & $\mathrm{y}=0.7948 \mathrm{x}-5.4287$ & 1.57847 & -5.4287 \\
& KS II & $\mathrm{y}=0.3112 \mathrm{x}-4.4711$ & -0.61804 & -4.4711 \\
\hline \multirow{3}{*}{ Ordo 1 } & KS 0 & $\mathrm{y}=0.9521 \mathrm{x}-6.2332$ & 1.89087 & -6.2332 \\
& KS I & $\mathrm{y}=0.7948 \mathrm{x}-5.4287$ & 1.57847 & -5.4287 \\
& KS II & $\mathrm{y}=0.3112 \mathrm{x}-4.4711$ & -8.8796 & -4.4711 \\
\hline
\end{tabular}

Table 8. Conclusion value of shelf life

\begin{tabular}{cccccc}
\hline \multirow{2}{*}{ Equation } & \multirow{2}{*}{ Formulation } & \multicolumn{3}{c}{ Shelf Life } & \multirow{2}{*}{ Mean } \\
\cline { 3 - 5 } & & $35^{\circ} \mathrm{C}$ & $45^{\circ} \mathrm{C}$ & $50^{\circ} \mathrm{C}$ & \\
\hline \multirow{2}{*}{ Ordo 0 } & KS 0 & 16 days & 17 days & 17 days & 17 days \\
& KS I & 9 days & 10 days & 10 days & 10 days \\
& KS II & 526 days & 543 days & 552 days & 540 days \\
& KS 0 & 217 days & 65 days & 66 days & 116 days \\
\multirow{2}{*}{ Ordo 1 } & KS I & 39 days & 40 days & 41 days & 40 days \\
& KS II & 2408 days & 2486 days & 2525 days & 2473 days \\
\hline
\end{tabular}

gradient obtained from the Arrhenius plot.

After the Arrhenius equation and the rate of change $\mathrm{a}_{\mathrm{w}} \mathrm{KS} 0$, KS I, KS II is obtained, the shelf life is searched at each temperature using the shelf life equation: $\mathrm{t}=(\ln \mathrm{A} 0-\ln \mathrm{A}) \mathrm{k}$. The result, as shown in Table 8 .

\section{Discussion}

\subsection{Energy and Nutrient Content}

\subsubsection{Energy}

The energy content of instant baby porridge in all three formulas is $503.33-522.62 \mathrm{kcal} / 100 \mathrm{~g}$. According to the provisions of the Ministry of Health Complementary feeding with instant baby porridge, the energy value of instant baby porridge complementary feeding is $400-440$ 
kcal per 100 g (Republic Indonesia Health Minister, 2007). According to the Recommended Dietary Allowances (RDA), the energy requirement in 7-11 months is $725 \mathrm{kcal} /$ day. The energy that can be fed from breast milk is $0.65 \mathrm{kcal} / \mathrm{ml}$ (National Research Council, 1989; Association of Indonesian Nutrition Higher Education Institutions (AIPGI), 2017). If the baby is breastfed with medium quality and quantity, an energy intake of $413 \mathrm{kcal}$ can be fulfilled through breast milk and the remaining $312 \mathrm{kcal}$ can be obtained from complementary feeding. The consumption of freshwater snail instant baby porridge (KS I) can meet the energy need of $14.41 \%$ in one serving ( $20 \mathrm{~g}$ ) according to Recommended Dietary Allowances (RDA).

About 6 months old, babies are growing quickly and need more energy and nutrients than at any other time in life. The energy needs in infancy are greater, with a Resting Metabolic Rate (RMR) twice as large as adulthood. Young children need enough nutritious food every day to grow healthy, strong and smart. It is used for baby's activity, growth and development (National Research Council, 1989; Association of Indonesian Nutrition Higher Education Institutions (AIPGI), 2017).

\subsubsection{Carbohydrate}

The results showed that the carbohydrates of the three samples had a significantly difference, which means the addition of freshwater snail flour affected the carbohydrate content of each sample. Carbohydrates are the main energy source for babies. Carbohydrate intake must meet at least $52-54 \%$ of energy needs. There are no specific requirements regarding the range of carbohydrate content in the complementary feeding specifications. Fulfillment of carbohydrate needs, about $45-65 \%$ comes from total calories from breast milk or around 130 g/day (National Research Council, 1989; Association of Indonesian Nutrition Higher Education Institutions (AIPGI), 2017).

Ingredients that high in carbohydrate content are such as rice flour, refined sugar, and full cream milk. The proportion of instant rice flour in 3 formula is the same $(35 \%)$, refined sugar $(5 \%)$ and full cream milk KS I (40\%) and KS II (35\%). The carbohydrate value is decreased because of the high percentage of protein and fat content produced in instant baby porridge.

\subsubsection{Protein}

Protein is a nutrient that is needed by the body for growth, building body structure (muscles, skin and bones), and as a substitute for tissues that are already using it as well as for the formation of new tissues and energy reserves in the body in the process of metabolizing essential nitrogen supply for synthesizing proteins in growing children (Almatsier, 2009; Semba et al., 2016). Infants aged of 6-12 months are in the critical period of rapid growth, and they are increasingly dependent on additional food. Consumption of animal protein in daily food is needed by the body in addition to vegetable protein.

The protein content of instant baby porridge complementary feeding with the substitution of freshwater snail flour ranged from 10.41-18.97\% per 100 g. In another study, Instant Baby porridge substituted with river shellfish flour $10 \%$ and $15 \%$ obtained a protein content of $12.1 \%$ and $11.5 \%$ (Putri et al., 2018).

Food source of protein used in instant baby porridge complementary feeding is freshwater snail flour. Freshwater snail is rich in protein, but low in fat so that it can be used as an alternative to high-protein foods that are low in fat. Freshwater snails contain an animal protein with a fairly high protein content that is equal to $12-50 \%$. In $100 \mathrm{~g}$ of formula (KS I) substituted $10 \%$ of freshwater snail flour contributes $1.5 \mathrm{~g}$ of protein, and for KS II formula, which is substituted $15 \%$ of freshwater snail flour contributes $2.25 \mathrm{~g}$ of protein. Complementary feeding instant powder for babies aged 6 -12 months, a protein content of 15-22 g/100 g of Instant baby porridge are required (Republic Indonesia Health Minister, 2007). Protein intake consumed from breast milk is $5-20 \%$ of total calories or $13 \mathrm{~g}$ /day. In fulfilling the protein requirements according to the RDA for children aged 7-11 months, the consumption of freshwater snail instant baby porridge (KS I) can meet the protein requirement of $17.7 \%$ in one serving $(20 \mathrm{~g})$.

\subsubsection{Fat}

The results showed that the fat content of the three samples showed a significant difference, which means the addition of freshwater snail flour affected the fat content in each sample. Instant baby porridge formula I (KS 0) has the highest fat content, which is $19.99 \%$. The fat content in formula (KS I) is $18.31 \%$ and formula (KS II) is $18.68 \%$. In breast milk, fatty acid content is $5.6 \mathrm{~g}$ per liter. The content of alpha linolenic acid and DHA is $0.63 \mathrm{~g}$ per liter (Association of Indonesian Nutrition Higher Education Institutions (AIPGI), 2017). According to the RDA requirements, the fat needs of children aged 7-11 months can be fulfilled $10.27 \%$ for the KS I formula, and $10.37 \%$ for the KS II formula per $20 \mathrm{~g}$ serving size.

Fats contained in snails are essential fatty acids in the form of linoleic acid (omega-6) and linolenic acid (omega-3).The fat in freshwater snail is an unsaturated fatty acid, unsaturated fatty acid can reduce blood cholesterol level. Omega-3 fatty acids play a role in brain 
intelligence and bone growth (Koren et al., 2014; Mulder et al., 2014). Omega-6 fatty acids play a role in preventing energy loss during the metabolic process so that it is useful to prevent energy deficiency (Jumbe et al., 2016). Omega 6 also plays a role in increasing the concentration of Growth Hormone $(\mathrm{GH})$ or growth hormone in the body (Jumbe et al., 2016)

\subsubsection{Crude fiber}

According to the Indonesia Health Minister, a maximum fiber content of $5 \mathrm{~g} / 100 \mathrm{~g}$ packaging. The results showed that the crude fiber content of the three samples showed significant differences, which means the addition of freshwater snail flour influenced the crude fiber content in each sample. The fiber content in the formulations of instant baby porridge were $2.44-3.99 \%$. Of the three formulas, the highest yield was obtained in the formula of instant baby porridge substituted with freshwater snail flour by $10 \%$ and the lowest yield was obtained in the formula of instant baby porridge without substitution of freshwater snail flour. Every addition of freshwater snail flour increased the crude fiber content of each formulation. Increased levels of fiber occurred because the fiber contained in freshwater snail meat expected a heating process that involved browning or Maillard reaction between amino acids and products resulted from sugar degradation (Stosse-wolthuis, 1981). In a food product that contains high crude fiber, it will potentially interfere with the absorption of nutrients such as protein, fat, vitamins, and other minerals needed by the body. Crude fiber also causes satiety more quickly because of the nature of the fiber that has a high-water absorption power.

\subsubsection{Ash}

Ash content in food has a relationship with mineral content which is an inorganic substance. The ash content in formula of instant baby porridge was obtained at 1.88$2.68 \%$. Ash content in instant baby porridge complementary feeding is concerned no more than 3.5 $\mathrm{g} / 100 \mathrm{~g}$. And all formulations do not get more than the value. Ash content has to do with minerals of an ingredient. The higher the temperature of drum drying will increase the ash content because an increase in the appropriate temperature in a drying process does not result in the destruction of nutrients, especially minerals. These increases only reduce the water content of the material. The amount of minerals in the body must be in optimal, if excess or deficit can interfere with the health.

\subsubsection{Water}

The results showed water content of instant baby porridge was significantly different, but it was not significantly different from the water content of instant baby porridge in formula (KS I) and formula (KS II). The water content of instant baby porridge ranged from 5.51 to $6.24 \%$. The highest water content was found in the complementary feeding formula of instant baby porridge substituted with $10 \%$ freshwater snail flour (KS I) and the lowest in the formula without substitution of freshwater snail flour (KS 0). According to the standard of Indonesia Health Minister, the water content in $100 \mathrm{~g}$ of instant powder complementary feeding is no more than 4\% (Republic Indonesia Health Minister, 2007). Water content at food ingredients greatly affect the quality of a food. Where the water content is very important in determining the durability of food products. That is because water content affects physical, chemical, microbiological changes and enzymatic changes in food.

The results of the study the water content in each formula exceeds the requirements. This is due to the freshwater snail flour has a high water content and the drying method using a drum dryer in making instant rice flour is indeed suitable for drying ingredients in the form of pasta, but will produce instant flour with water higher than other drying methods (Hsu et al., 2003).

\subsubsection{Iron}

The iron content found in freshwater snails is included in heme iron, heme iron is an iron that is easily absorbed by cells due to the low phytate content in animal foods (Magallanes-lópez et al., 2017). In Table 2, the iron from the three samples shows a significant difference, which means the addition of freshwater snail flour affects the iron content in each sample. The iron content in the formula is $1.88-6.61 \mathrm{mg} / 100 \mathrm{~g}$. According to (Republic Indonesia Health Minister, 2007) value of iron content in $100 \mathrm{~g}$ that is equal to $5-8 \mathrm{mg}$.

The iron content of freshwater snail meat is 10.90 $\mathrm{mg} / 100 \mathrm{~g}$. In fulfilling the protein according of RDA aged 7- 11 months, consumption complementary feeding can the requirement iron of $11.25 \%$ in one serving ( 20 g). Meanwhile, complementary feeding fortified with chicken liver flour with iron content of $4 \mathrm{mg}$, will make the iron content in complementary feeding to be 123.80 $\mathrm{mg} / 100 \mathrm{~g}$ of formula (Santosa et al., 2016). The role of iron $(\mathrm{Fe})$ is as an enzyme component as well as a cytochrome component that influences growth. One of them is as a component of the ribonucleotide reductase enzyme which is able to participate in DNA synthesis that works indirectly on tissue growth that can affect growth. Iron is also related to oxidation and reduction reactions in the body, for example in the activation of myoglobin, and its role in binding proteins to prevent the potential effects of oxygen destruction in the blood (Mahan et al., 2012). 


\subsubsection{Zinc}

The results of the zinc content of the three samples showed a significant difference, it means the addition of freshwater snail flour influenced the zinc content in each sample. The zinc content in instant freshwater snail baby porridge is $1.03-1.61 \mathrm{mg} / 100 \mathrm{~g}$ formula. $100 \mathrm{~g}$ of snail's meat contains $1.31 \mathrm{mg}$ of zinc. This supports the zinc content in the formula that is equal to $1.03-12.20 \%$. According to RDA, the zinc needs of children aged 7-11 months can be fulfilled by $10 \%$ for the KS I formula, and $10.7 \%$ for the KS II formula per $20 \mathrm{~g}$ serving size. In another study, zinc content in baby porridge substituted with $10 \%$ and $15 \%$ freshwater snail obtained zinc levels which were quite high at $3.7 \mathrm{mg}$ and $4.7 \mathrm{mg} / 100 \mathrm{~g}$ of formula (Putri et al., 2018).

Zinc is an essential substance in the body related to metabolism and absorption in the body especially in the bones (Lonnerdal, 2000). Zinc interacts with important hormones involved in bone growth such as somatomedin, osteocalcine, testosterone, thyroid and insulin. Zinc plays a role in the production of growth hormone (GH) (Agustian et al., 2009; Alves et al., 2012; Setiawan et al., 2015). Children with zinc deficiency 2.67 at more risk of stunting (Hidayati et al., 2010). Zinc deficiency inhibits the metabolism of thyroid hormones, androgens and especially growth hormone. Growth will be inhibited if the body has zinc deficiency (Semba et al., 2016).

\subsubsection{Calcium}

Calcium is the main mineral needed in the process of bone formation. As much as $99 \%$ of calcium a body in the bones, the remaining $1 \%$ in the blood, extracellular fluid and in cells the body. Calcium is the biggest component in bones, so the intake of calcium from food is important to increase bone strength and health (Palacios and Weaver, 2013). Low calcium intake can affect health, especially growth problems and other health problems related to calcium function inside the body. The results showed that the calcium content of the three samples showed a significant difference, means the addition of freshwater snail flour influenced the calcium content in each sample. The calcium content in formula is $208.45-621.55 \mathrm{mg} / 100 \mathrm{~g}$ of instant baby porridge. Provisions to (Republic Indonesia Health Minister, 2007) value of calcium content in $100 \mathrm{~g}$ is $200-400 \mathrm{mg}$. The highest calcium value was found in the formula instant baby porridge substituted with rice conch flour by $15 \%$ (KS II) and the lowest value was found in the formula (KS 0). A $100 \mathrm{~g}$ of snail meat contain $129 \mathrm{mg}$ of calcium. The consumption of freshwater snail instant baby porridge (KS I) can meet the calcium needs of $35.10 \%$ and KS II $49.7 \%$ in one serving ( $20 \mathrm{~g}$ ).

\subsection{Acceptance (hedonic test)}

Acceptability test is one thing that needs to be assessed on a product. Grading methods for food and beverage products, traditionally involved one or two trained "experts" assigning quality scores on the appearance, flavour and texture of the products based on the presence or absence of predetermined defects (Singhackbarali and Maharaj, 2014).

\subsubsection{Color}

Color is one of the first acceptable evaluations of the eye so that the color can respond quickly and easily in giving the impression of a product. If the color of a food is not attractive even though the nutritional content is complete and the taste is good, it can reduce the level of product acceptance. The results of the statistical tests show that there are differences in the color of the three formulations of instant baby porridge with the substitution of freshwater snails' flour. The panelists tend to prefer KS 0 formulation (control) and KS I, but they dislike the color of KS II because of the darker color and unattractiveness. This is because the color of freshwater snail meat is yellowish. The process of boiling the meat make it pale. Drying process and flour making cause the color of freshwater snail to be dark gray. This is thought due to the non-enzymatic browning process, namely the Maillard reaction in the repeated drying process.

\subsubsection{Aroma}

The aroma or odor associated with food products is sensed by olfactory receptors in nasal epithelium. Hence, for the detection of aroma or odor, volatile molecules must be shifted to the nasal cavity. These compounds further move in the nose during inhaling or breathing or during eating through the back of the throat (Sharif et al., 2017). The aroma in formulation of instant baby porridge tends to be disliked because it is a bit fishy. The snail's fishy smell characteristic is caused by the presence of trimethylamine in the freshwater snail meat. Meat that contains lots of fat and pro-oxidants can be a major cause of changes in a aroma (Marsyha et al., 2018). The compounds that play a role in the aroma of the freshwater snail are volatile sulfur, hydrogen sulfide, methyl mercaptan, methyl sulfide and sugar, namely ribose glucose and glucose 6 phosphate.

\subsubsection{Texture}

Texture is perceived by a combination of senses i.e. touch, mouthfeel, sight and hearing. It is one of the most 
imperative feature of a food. Texture is prerequisite in the acceptance of numerous foodstuffs e.g. tenderness of meat and softness of dough. It also includes the consistency, thickness, fragility, chewiness, the size and shape of particles in food (Sharif et al., 2017). Texture of instant baby porridge in the KS 0 and KS I formulas are preferred by panelists. The texture of KS II Formula is not preferred because the texture is less smooth and rather too lumpy. This is significantly influenced by the substitution of freshwater snail flour (Pila ampullacea). Because of the higher the rate of addition of freshwater snail flour, the texture is solid and lumpy. The lumpy texture is caused by the content of actomyosin in the freshwater snail protein (Putri et al., 2018).

\subsubsection{Taste}

Taste involves the perception of constituents after being dissolved in saliva, oil or water by taste receptors in the taste buds found superficially on the tongue and other parts of the mouth or gullet (Sharif et al., 2017). According to the results of the average calculation using taste statistics from the three formulas is not preferred. Because the KS 0 formula, according to panelists, tastes less sweet, and too milky. KS I Formula, according to panelists, has a bit of fishy taste but still acceptable. Some say that it tastes good and likes it. But for the KS II formula, the taste was too fishy and many panelists were less acceptable.

\subsection{Shelf life}

Deviation of a product from its initial quality is called deterioration. Food products undergo deterioration immediately after being produced. The deterioration reaction starts with contact of the product with air, oxygen, steam, water, light or changes in temperature. The rate of deterioration is influenced by the length of storage, while the rate of deterioration is influenced by the conditions of the storage environment. In this study, shelf life is tested using ASLT (accelerated shelf-life testing) method, the calculations using Arrhenius equation. In this method, temperature is a factor that influences changes in food. The higher the storage temperature, the reaction rates of various chemical compounds will be faster. The assumption used this model is that changes in quality factors are only found by one type of reaction. No other factors occur that result in changes in quality. The process of changing the quality is not considered as a result of processes that occur before, the temperature during storage is considered constant.

Shelf life is the time until the product experiences a certain level of deterioration. In contrast, when alterative events occur slowly, it might be much more useful to accelerate shelf life tests by monitoring food quality depletion under environmental conditions that allow deterioration events to proceed faster. If properly applied, this procedure, known as accelerated shelf life testing (ASLT), allows estimation of the shelf life data at storage conditions usually experienced by the product on the market by using data acquired at accelerated storage conditions (Calligaris et al., 2019).

Instant products are sensitive to changes in surrounding levels. Therefore, the stability of dry products is determined by 2 main factors, one of which is $a_{w} \cdot a_{w}$ is defined as free water or available in food products, so the value of aw greatly influences the growth of microbes in food. The $\mathrm{a}_{\mathrm{w}}$ of dried milk products is largely correlated with moisture content and temperature (Rodel, 2001).

The shelf life of food is generally influenced by both physical changes and chemical reactions, and for food powder, both are controlled by the availability of water. It is mainly the chemical and physical stability which are controlling the quality of food powder, since the $\mathrm{a}_{\mathrm{w}}$ is far below the limit for microbial growth (Labuza et al., 1970). Different environmental factors, such as temperature, oxygen, light, and relative humidity, could be potentially exploited as accelerating factors (AF) in ASLT (Calligaris et al., 2019). This method uses environmental conditions that can accelerate the reaction of a decrease in the quality of food products. Food products are stored at extreme temperature conditions where damage to food products occurs faster so that the critical parameters decrease in quality due to the influence of heat. The higher the storage temperature, the reaction rates of various chemical compounds will be increasingly fast. Dried foods classified as food powders are sensitive to heat, moisture, access to oxygen and to exposure to light as he most critical external factors in determining their shelf life (Hedegaard and Skibsted, 2013). Thus, the critical parameter used in estimating the shelf life of Instant baby porridge complementary feeding products is $\mathrm{a}_{\mathrm{w}}$, which justification the Total Plate Count (TPC) value that can dominate the product is broken.

The test temperature used is $35^{\circ} \mathrm{C}$ (which is the range of dry product testing and at this temperature is the optimum temperature for bacterial growth), $45^{\circ} \mathrm{C}$, (included in the shelf life test temperature according to dry product rules) and $50^{\circ} \mathrm{C}$ (Labuza and Schmidl, 1985) with an incubation period of 15 days. Then, the product will be tested on days $0,5,10$ and 15 . Critical point value of ordo 0 is 0.32 and ordo 1 is -1.14 . Determination of shelf life of (Pila ammpullacea) instant baby porridge complementary feeding based on of ordo 1 because the value of $a_{w}$ is more justifying the growth of 
total bacteria in total place count (TPC) method. But, in determining the calculation of the order can be seen from the large value of $\mathrm{R}^{2}$ in each Arrhenius equation, a large $\mathrm{R}^{2}$ value will be used as a reference equation in calculating the shelf life of the product in the treatment of each temperature.

Through the shelf life calculation, the shelf life of instant baby porridge complementary feeding product is, the KS 0 formula with the temperature $35^{\circ} \mathrm{C}$ has a shelf life of 7.13 months, $45^{\circ} \mathrm{C}$ has a shelf life of 2.13 months and $50^{\circ} \mathrm{C}$ has a shelf life of 2.16 months. KS I Formula at a temperature of $35^{\circ} \mathrm{C}$ has a shelf life of 39 days, $45^{\circ} \mathrm{C}$ has a shelf life of 40 days and $50^{\circ} \mathrm{C}$ has a shelf life of 41 days. KS II Formula at a temperature of $35^{\circ} \mathrm{C}$ has a shelf life of 6 years 7 months, $45^{\circ} \mathrm{C}$ has a shelf life of 6 years 8 months and $50^{\circ} \mathrm{C}$ has a 6 years 9 months shelf life.

The results of the calculation of shelf life obtained the final value that is not according to theory. Supposedly, the higher the storage temperature, the reaction rates of various chemical compounds will be increasingly fast and a shorter shelf life. Because food powders are sensitive to heat, moisture, access to oxygen and exposure to light as the most critical external factors in determining their shelf life. The results actually the opposite and the value is fluctuated. This occurs due to several factors i.e., research tool is not functioning normally so that the test results have fluctuating values, and the location of the test that is not done in one place so the possibility of contamination from external factors.

\subsection{Selection of formula and contribution to nutritional adequacy}

Determination of the serving size is important to be advised on food serving and labeling. Before the measurement of serving sizes, it will be necessary to choose the appropriate product/best formula. The best formula is chosen based on the results of the comparison of the value nutrient content with the provisions of Indonesian Health Minister and the results of consumer acceptance.

In Figure 1, consumer acceptance result of instant baby porridge, which is KS 0 formula is preferred by consumers than KS I and KS II. The chosen formula is a formula with freshwater snail flour substituted, so formula KS I is chosen because consumers liked the color and texture of the instant baby porridge. Consumers do not like the aroma and taste of it, but it can be viewed from the average result. The value is not bad because it is almost in the preferred category.

The analysis of nutrient content compared to each formula with the provisions of the Indonesian Health Minister, best formula obtained is KS II. But because the consumer's acceptance value in the KS II formula tends to dislike the KS II formula, another alternative formula is chosen, the KS I formula. KS I Formula becomes the reference formula for serving size, contribution in one serving is $20 \mathrm{~g}$, which can meet the energy adequacy of $14.41 \%$, the adequacy of carbohydrates $15.36 \%$, the adequacy of protein $17.7 \%$, the adequacy of fat $10.27 \%$,

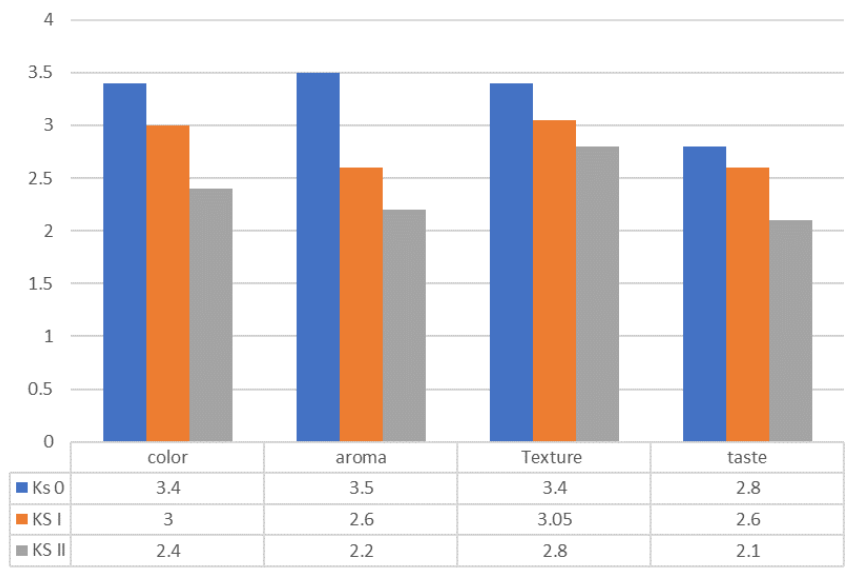

Figure 1. Results of acceptance test of instant baby porridge complementary feeding

the adequacy of fiber $1.7 \%$, water adequacy $0.16 \%$, iron adequacy $11.25 \%$, zinc adequacy $10 \%$, calcium adequacy $35.10 \%$. See more details in Table 9 .

Table 9. Nutritional contribution of complementary feeding intake of freshwater snail instant baby porridge (KS I) (20 g) Formulation 2 (KS I)

\begin{tabular}{cccccc}
\hline Nutrient & $\begin{array}{c}\text { Value of } \\
\text { nutrient }(100 \mathrm{~g})\end{array}$ & $\begin{array}{c}\text { (Republic Indonesia } \\
\text { Health Ministry, 2007) }\end{array}$ & $\begin{array}{c}\text { Value of } \\
\text { nutrient }(20 \mathrm{~g})\end{array}$ & RDA & $\begin{array}{c}\% \mathrm{RDA} \\
(20 \mathrm{~g})\end{array}$ \\
\hline Energy (kcal) & 522.62 & $440-440$ & 104.5 & 725 & $14.41 \%$ \\
Carbohydrate $(\mathrm{g})$ & 63.01 & - & 12.6 & 82 & $15.36 \%$ \\
Fat $(\mathrm{g})$ & 18.31 & $10-15$ & 3.7 & 36 & $10.27 \%$ \\
Protein $(\mathrm{g})$ & 16.18 & $15-22$ & 3.2 & 18 & $17.70 \%$ \\
Fiber (g) & 3.55 & Max 5 & 0.71 & 10 & $1.70 \%$ \\
Water (g) & 6.24 & Max 4 & 1.25 & 800 & $0.16 \%$ \\
Ash (g) & 2.49 & 3.5 & 0.5 & - & - \\
Iron (mg) & 4.72 & $5-8$ & 0.9 & 8 & $11.25 \%$ \\
Zinc (mg) & 1.27 & $2.5-4.0$ & 0.3 & 3 & $10 \%$ \\
Calcium (mg) & 438.8 & $200-400$ & 87.76 & 250 & $35.10 \%$ \\
\hline
\end{tabular}




\section{Conclusion}

There was a significant effect of substitution of freshwater snail flour with a treatment level of $0 \%, 10 \%$ and $15 \%$ on the nutrient content of carbohydrates, proteins, fats, crude fiber, water content, ash content, iron, zinc, and calcium $(\mathrm{P}<0.005)$. Based on the analysis of nutrient content compared with acceptance product, the best formula obtained is KS I, KS I Formula becomes the reference formula for serving size, contribution in one serving is $20 \mathrm{~g}$, which is fulfilled the energy adequacy of $14.41 \%$, carbohydrates $15.36 \%$, protein $17.7 \%$, fat $10.27 \%$, fiber $1.7 \%$, water $0.16 \%$, iron $11.25 \%$, zinc $10 \%$, calcium $35.10 \%$. The shelf life at the temperature of $35^{\circ} \mathrm{C}$ is 39 days, $45^{\circ} \mathrm{C}$ has a shelf life of 40 days and $50^{\circ} \mathrm{C}$ has a shelf life of 41 days.

\section{Conflict of interest}

The authors declare that there is no conflict of interest.

\section{Acknowledgments}

The authors acknowledge that this research was funded by the grant from PNBP Faculty of Medicine, University of Diponegoro, Semarang. The author would like to thank all the parties involved and support this research.

\section{References}

Actia. (2001). Sensory Evaluation. Retrieved from website: https://db.iseki-food.net/sites/default/files/ digital_library_attachments/ act_e769val_senso_angl_2001_0.pdf

Agustian, L., Sembiring, T. and Ariani, A. (2009). The Role of Zink on Child Growth. Sari Pediatri, 11(4), $7-12$.

Almatsier, S. (2009). Basic Principles of Nutrition. Jakarta: PT. Gedia Pustaka Utama.

Alves, C.X., Vale, S.H., Dantas, M.M., Maia, A.A., Franca, M.C., Marchini, J.S., Leite, L.D. and Brandao-Neto, J. (2012). Positive effects of zinc supplementation on growth, GH, IGF1, and IGFBP3 in eutrophic children. Journal of Pediatric Endocrinology and Metabolism, 25(9-10), 881-887. https://doi.org/10.1515/jpem-2012-0120

Asiah, N., Cempaka, L. and David, W. (2018). Estimation of the shelf life of food products. South Jakarta: Bakrie University.

Association of Indonesian Nutrition Higher Education Institutions (AIPGI). (2017). Nutrition Theory and Application. Jakarta: EGC Medical book.

Ayustaningwarno, F. (2014). Practical food technology theories and applications. 1st ed. Yogyakarta: Graha Ilmu.

Calligaris, S., Manzocco, L. and Anese, M. (2019). Accelerated shelf life testing'. In Galanakis, M. (Ed.) Food Quality and Shelf Life, p. 359-392. Italy: Elsevier Inc. https://doi.org/10.1016/B978-0-12817190-5.00012-4

Cesa, S., Maria, A.C., Felice, C. and Patrizia, P. (2015). Infant Milk Formulas: Effect of Storage Conditions on the Stability of Powdered Products towards Autoxidation. Journal Foods, 4(3), 487-500. https:// doi.org/10.3390/foods4030487

Hadiningsih, N. (2004). Optimization of ASI Complementary Food Formula by Using Response Surface Methodology. Bogor, Indonesia: Institut Pertanian Bogor.

Hedegaard, R.V. and Skibsted, L.H. (2013). Shelf-life of food powders. In Bhandari, B., Bansal, N., Zhang, M. and Schuck, P. (Eds.). Handbook of food powders, processes and properties. 1st ed., p. 409434. Denmark: Woodhead Publishing Limited. https://doi.org/10.1533/9780857098672.2.409

Herawati, H. (2008). Determination of shelf life in food products. Agricultural Research and Development, 27(4), 124-130.

Hidayati, L., Hadi, H. and Kumara, A. (2010). Deficiency of Energy and Nutrients Is a Risk of Stunted Occurrence in Children Aged 1-3 Years Live in Urban Slums in Surakarta. Health Journal, 3(1), 89-104.

Hsu, C.-L., Chen, W.L., Weng, Y.-M. and Tseng, C.-Y. (2003). Chemical composition, physical properties, and antioxidant activities of yam flours as affected by different drying methods. Food Chemistry, 83(1), 85-92. http://doi.org/10.1016/S0308-8146(03)00053 -0 .

Jumbe, T., Sarah, S.C., Samantha, L.H., William, S.H., Joyce, K. and Jenifer, I.F. (2016). Whole Blood Levels of the n-6 Essential Fatty Acid Linoleic Acid Are Inversely Associated with Stunting in 2-to-6 Year Old Tanzanian Children: A Cross-Sectional Study. PLOS ONE, 11(5), 1-19. https:// doi.org/10.1371/journal.pone.0154715

Komalamisra, C., Nuamtanong, S. and Dekumyoy, P. (2009). Pila Ampullacea and Pomacea Canaliculata, as New paratenic Hosts of Gnathostoma Spiningerum. Journal Tropical Medicine Public Health, 40(2), 243-246.

Koren, N., Simsa-Maziel, S. Shahar, R., Schwartz, B. and Monsonego-Ornan, E. (2014). Exposure to omega-3 fatty acids at early age accelerate bone growth and improve bone quality. The Journal of 
Nutritional Biochemistry, 25(6), 623-633. https:// doi.org/10.1016/j.jnutbio.2014.01.012.

Kusumawardani, B. (2010). Relationship of Hygiene Practices of Sanitary Food Complementary Traditional Mother's Milk (MP-ASI) with the incidence of diarrhea in children aged 6-24 months in Semarang city. Indonesia: Universitas Diponegoro.

Labuza, T.P. and Schmidl, M.K. (1985). Accelerated shelf life testing of food. Food Technology, 39, 5467.

Labuza, T.P., Tannenbaum, S. and Karel, M. (1970). Water content and stability of low-moisture and intermediate-moisture foods. Food Technology, 24 (5), 543-544.

Lim, J. (2011). Hedonic scaling: A review of methods and theory. Food Quality and Preference, 22(8), 733 -747. https://doi.org/10.1016/j.foodqual.2011.05.008

Lonnerdal, B. (2000). Zinc and Health: Current Status and Future Directions Dietary Factors Influencing Zinc Absorption. The Journal of Nutrition, 130(5), 1378-1383. doi: https://doi.org/10.1093/ jn/130.5.1378S.

Magallanes-lópez, A.M., Hernandez-Espinosa, N., Govindan, V., Posadas-Romano, G., OrdoñezVillegas, V.M.G., José, C., Karim, A. and Carlos, G. (2017). Variability in iron, zinc and phytic acid content in a worldwide collection of commercial durum wheat cultivars and the effect of reduced irrigation on these traits. Food Chemistry, 237, 499505. https://doi.org/10.1016/j.foodchem.2017.05.110

Mahan, K.L., Raymond, J. and Escott-Stump, S. (2012). Krause's Food and the Nutrition Care Process. 13th ed. USA: Elsevier.

Marsyha, D.D., Wijayanti, H.S., Nuryanto and Anjani, G. (2018). Contribution of Golden Apple Snail Flour to Enhance Omega- 3 and Omega-6 Fatty Acids Contents in Weaning Food. IOP Conference Series: Earth and Environmental Science PAPER, 116, 012075. https://doi.org/10.1088/17551315/116/1/012075

Mulder, K.A., King, D.J. and Innis, S.M. (2014). Omega -3 Fatty Acid Deficiency in Infants before Birth Identified Using a Randomized Trial of Maternal DHA Supplementation in Pregnancy. PLOS ONE, 9 (1), 19-22. https://doi.org/10.1371/ journal.pone. 0083764

National Research Council. (1989). Recommended Dietary Allowances. $10^{\text {th }}$ ed., p. 24-38. Washington, D.C., USA: National Academic Press.

Nurhasan, M., Hanne, K.M., Marian, K.M., Svein, K.S., Matthias, H., David, J. and Edel, O.E. (2010).
Nutritional composition of aquatic species in Laotian rice field ecosystems. Journal of Food Composition and Analysis, 23(3), 205-213. https:// doi.org/10.1016/j.jfca.2009.12.001

Obande, R.A., Omeji, S. and Isiguzo, I. (2013). Proximate composition and mineral content of the Freshwater snail (Pila ampullacea) from River Benue, Nigeria. Journal of Environmental Science, Toxicology and Food Technology, 2(6), 43-46. https://doi.org/10.9790/2402-0264346

Oktasari, N. (2014). Utilization of Rice Snail (Pila ampullacea) in Making Nugget as an Alternative High-Protein Food in Jurug Village, Mojosongo, Boyolali. Indonesia: Universitas Negeri Semarang.

Palacios, C. and Weaver, C.M. (2013). Calcium Metabolism in Mexican American Adolescents. In Burckhardt, P., Dawson-Hughes B. and Weaver, C. (Eds.) Nutritional Influences on Bone Health. 8th ed. London: Springer. https://doi.org/10.1007/978-14471-2769-7_34

Putri, S R., Anjani, G. and Wijayanti, H.S. (2018). Freshwater Clams (Pilsbryoconcha exilis) as an Potential Local Mineral Sources in Weaning Food to Overcome Stunting in Grobogan, Central Java, Indonesia. IOP Conference Series: Earth and Environmental Science, 116, 012077. https:// doi.org/10.1088/1755-1315/116/1/012077

Republic Indonesia Health Ministry. (2007). Technical Specifications of Breast Milk Complementary Food (MP-ASI) Instant Powder for babies 6-12 months. Jakarta: Republic Indonesia Health Ministry.

Rodel, W. (2001). Water activity and its measurement in food. In Rogers, K.E. and Brimelow, C.B. (Eds) Instrumentation and sensors for the food industry. 1st ed., p. 453 - 482. Kulmbach: Woodhead Publishing. $\quad$ https:// doi.org/10.1533/9781855736481.2.453

Santosa, H., Abyor Handayani, Nuramelia, N., Yunita, C., Tunggal Sukma, N. (2016). Utilization of chicken liver as fortification of iron in instant baby porridge from purple sweet potato. Chemical Engineering Innovation, 1(1), 27-34.

Semba, R.D., Shardell, M., Sakr Ashour, F.A., Moaddel, R., Trehan, I., Maleta, K.M., Ordiz, M.I., Kraemer, K., Khadeer, M.A., Ferrucci, L. and Manary, M.J. (2016). Child Stunting is Associated with Low Circulating Essential Amino Acids. EbioMedicine, 6, 246-252. https://doi.org/10.1016/ j.ebiom.2016.02.030

Setiawan, C.N., Sarosa, G.I. and Setiawati, M. (2015). Paediatrica Indonesiana. Paediatrica Indonesiana, 55(1), 23-28. https://doi.org/10.14238/ pi55.1.2015.23-8 
Sharif, M.K., Butt, M.S., Sharif, H.R. and Nasir, M. (2017). Sensory Evaluation and Consumer Acceptability. In Zahoor, T. and Butt, M.S. (Eds) Handbook of Food Science and Technology, p. 362386. Pakistan: UAF Press.

Stosse-wolthuis, M. (1981). Influence of Dietary Fibre on Cholesterol Metabolism and Colonic Function in Healthy Subjects. In Bourne, G.H. (Ed.) World Review of Nutrition and Dietetics, Human Nutrition and Diet, p. 100-140. Grenada, West Indies: Karger Publishing. https://doi.org/10.1159/000393155.

Trahms, C.M. and McKean, K.N. (2008). Nutrition During Infancy. In Mahan, L.K. and Escott-Stump, S. (Eds.) Krause's Food and Nutrition Therapy. Canada: Elsevier.

Victora, C.G., Adair, L., Fall, C., Hallal, P.C., Martorell, R., Richter, L., Sachdev, H.S. and for the Maternal and Child Undernutrition Study Group. (2008). Maternal and Child Undernutrition 2" Maternal and child undernutrition: consequences for adult health and human capital., The Lancet, 371(9609), 340-357. https://doi.org/10.1016/S0140-6736(07)61692-4

WHO. (1995). WHO model prescribing information: drugs used in parasitic diseases. 2nd ed. Geneva: WHO.

WHO. (2000). Complementary Feeding: Family foods for breastfed children. Geneva: WHO. 